\title{
Great and Little Traditions in Egyptology
}

\author{
Richard Bussmann
}

Ancient Egypt has much to offer to anthropologists, as Judith Lustig's 1997 volume "Egyptology and anthropology: a developing dialogue" rightly demonstrates. ${ }^{1}$ Not all contributors to the volume were equally optimistic about a potential "remarriage" of the two disciplines. ${ }^{2}$ However, one among other overlapping fields of interest is the role of "great and little traditions" in pre-modern societies. Popular in post-WW II anthropology, the topic entered Egyptology in the late 1980s as part of a discussion of the local temples in early Egypt. These temples functioned as community shrines in the Third millennium and later developed into grand monuments of royal display in the Second and First millennia.

The transfer of the terms "great tradition" and "little tradition" into Egyptology demonstrates that ancient Egypt can be aligned meaningfully with anthropological agendas. However, interpretation of the terms varies both within anthropology and Egyptology and requires some thoughts on the ways in which they can be applied to the Egyptian evidence. This paper compares the different uses of the terms to assess the potential and difficulties arising from interdisciplinary borrowing. I will begin with a comment on the research context of Third millennium temples in Egyptology outlined in greater depth elsewhere. ${ }^{3}$ The second part reviews relevant arguments in the discussion of great and little traditions in anthropology and shows how they might translate into Egyptology. References to great and little traditions by Egyptologists are usually couched in synthetic arguments. These will be reviewed in the third section. In the conclusion, I argue that debates of agency and practice are beneficial contexts for future research of early community shrines and of great and little traditions in ancient Egypt more generally.

\section{Third millennium community shrines in Egypt: history and research context}

Current debates of the earliest shrines in Egypt originate in the diachronic outline of temple development offered in 1989 by Barry Kemp. ${ }^{4}$ Kemp distinguished the "formal" layout of

1 J. Lustig (ed.), Anthropology and Egyptology. A Developing Dialogue, Sheffield 1997.

2 W. Y. Adams, Anthropology and Egyptology: Divorce and Remarriage? in: J. Lustig (ed.), Anthropology andEgyptology, 25-32. More optimistic: J.BAINES, Egyptology and the Social Sciences: Thirty Years On, in A. Verbovsek/B. Backes/C. Jones,(Hgg.), Methodikund Didaktikin der Ägyptologie. Herausforderungen eines kulturwissenschaftlichen Paradigmenwechsels in den Altertumswissenschaften, München 2011, 573-597; R. Bussmann, Egyptian Archaeology and Social Anthropology. Oxford Handbook of Archaeology Online 2015. DOI: 10.1093/oxfordhb/9780199935413.013.24.

3 R. Bussmann, Die Provinztempel Ägyptens von der 0. bis zur 11. Dynastie. Archäologie und Geschichte einer gesellschaftlichen Institution zwischen Residenz und Provinz, PÄ 30, Leiden 2010.

4 B. J. Kemp, Ancient Egypt. Anatomy of a civilization, London 1989, 65-83; ${ }^{2} 2006,111-135$. The references in this paper follow the second edition. 
Middle Kingdom and later temples from a "preformal" tradition typical of the simple shrines in the Early Dynastic period and the Old Kingdom. He showed that Middle Kingdom kings penetrated into local communities and replaced their shrines with temples of standardised royal format, which include decoration and inscriptions that centre on kingship.

A few years later, David O'Connor questioned that these early shrines were the true forerunners of later royal temples. ${ }^{5} \mathrm{He}$ believed that the earliest temples had not yet been discovered and that they must have been more similar in style and size to the examples of royal monuments of the Early Dynastic period known from excavations.

Stephan Seidlmayer returned to Kemp's model and emphasised the relevance of historical context. ${ }^{6} \mathrm{He}$ argued that kings developed different strategies for connecting with local deities in different periods: building shrines for deities surrounding royal ideology in the Early Dynastic period when the state was established; an almost entire lack of royal temple building initiative in the high Old Kingdom when kings focused on their funerary cult; and the implementation of royal statue cults in provincial community shrines across the country, when the latter had emerged as the power bases of local elites.

Following this line of thought, I have tried to extend the discussion from the architecture and inscriptions of early shrines, which reflect the royal perspective, into the local votive material associated with them. The comparison of the votive assemblages from shrine to shrine shows that each site followed a locally specific trajectory, reflecting the macro-historical development towards increasing royal patronage of Egyptian temples on the one hand and the micro-history of individual sites on the other.

Kemp has set the scene for the debate and it is worth revisiting some of his arguments. His division into "preformal" and "formal temples" opened research into the earliest shrines for questions different from those more commonly raised in the context of their "formal" successors, where royal ideology, ritual texts and theology prevail in scholarly analysis. The term "preformal" has been an important step towards modelling the social contexts of early community shrines. However, it can be misleading when mapped too narrowly on a single historical period because it implies that all later shrines were "formal", i.e. built and controlled by kings. A counter-example is the small Second Intermediate Period shrine at Gebel Zeit.? This shrine shows that people could articulate their religious needs outside the confines of royal patronage even after the Third millennium.

A key argument in Kemp's discussion is the lack of standardization of early shrines both on the level of architecture and votive objects. In plate 40 of his book, Kemp assembles a range of votive objects of diverse materials and shapes to substantiate his argument. ${ }^{8} \mathrm{Al}$ though compelling in principle, the plate implicitly takes the view of the political centre on local shrines. Seen from there, diversity is, indeed, striking. However, from a local per-

5 D. O'Connor, The status of early Egyptian temples. An alternative theory, in: B. AdAms/R. Friedman (ed.), The Followers of Horus. Studies dedicated to Michael Allen Hoffman 1944-1990, Oxford 1992, 83-98.

6 S. J. Seidlmayer, Town and state. A view from Elephantine, in: J. Spencer (ed.), Aspects of early Egypt, London 1996, 108-127, here 115-119.

7 G. Pinch, Votive Offerings to Hathor, Oxford 1993, 71-77.

8 Kemp, Ancient Egypt, fig. 40. 
spective, styles and features are more repetitive. ${ }^{9}$ For example, the ivory figurines found at Tell el-Farkha are consistently quite small as opposed to the highly polished, large ivory figurines from Hierakonpolis. ${ }^{10}$ Similarly, the architecture of early shrines is fairly repetitive on a local level when looked at diachronically. Elephantine (Fig. 1) and Tell Ibrahim are to date the best examples for this question because their architectural development has been recorded at a high chronological resolution. ${ }^{11}$ At both sites, the shrines were rebuilt in regular intervals throughout the Third millennium, but their layout remained almost entirely unchanged. This suggests that, the locals probably had a rather clear idea of how a temple looked like. Only from a central, comparative perspective do these shrines look diverse.

Due to the absence of texts and images, interpretation of the idiosyncratic architecture and the votive material found in early shrines is, perhaps, less straight forward than it is for later periods. Kemp interprets the temple of Elephantine as having an open forecourt and a closed sanctuary, both sheltering the statue of the local deity. ${ }^{12} \mathrm{He}$ calls the forecourt the "realm of the revealed image" and the sanctuary the "realm of the hidden image". However, there are alternative suggestions for a reconstruction and the "forecourt" might very well have been roofed. ${ }^{13}$ Kemp's reconstruction is helpful for exploring the imagined concepts underlying local temple architecture, but might ultimately be informed too heavily by later royal temple architecture and contemporaneous pyramid temples, which combine open forecourts with a roofed rear part.

Dieter Eigner argued that the shrine of Tell Ibrahim Awad would represent two hieroglyphs built in mud brick, the $h w t$-sign (domain) and the $h$-sign (plan of a building). ${ }^{14}$ Although a perfectly possible interpretation, it silently makes the temple fit for the glasses of elite written culture developed at court. The local flavour of the temple, which is most striking in the archaeological record, is thus overwritten in the interpretation.

David O'Connor's believed that the local temples must have had large enclosure walls comparable to the wall surrounding the later temple of Hierakonplis and the funerary en-

9 R. Bussmann, Local traditions in early Egyptian temples, in: R. F. Friedman/P. N. Fiske (ed.), Egypt at its Origins 3. Proceedings of the Third International Conference "Origin of the State. Predynastic and Early Dynastic Egypt”, London, 27th July - 1st August 2008, OLA 205, Leuven 2011, 747-762.

10 K. M. Ciąowicz, Early Egyptian objects of art, in: M. ChŁodnicki/K. M. Ciąowicz/A. Mączyńska (ed.), Tell el-Farkha I. Excavations 1998-2011, Cracow 2012, 201-244.

11 For Elephantine, see G. Dreyer, Elephantine VIII. Der Tempel der Satet. Die Funde der Frühzeit und des Alten Reiches, AV 39, Mainz am Rhein 1986. A useful discussion of this temple is offered by P. Kopp/D. Raue, Reinheit, Verborgenheit, Wirksamkeit. Innen-, An- und Außensichten eines ägyptischen Sanktuars jenseits der zentralen Residenzkulte, in: Archiv für Religionsgeschichte 10, 2008, 31-50. For Tell Ibrahim Awad, see D. Elgner, Tell Ibrahim Awad. Divine residence from Dynasty 0 until Dynasty 11, in: Ä\&L 10, 2000, 17-36; D. EIGNER, Design, space and function. The Old Kingdom temple of Tell Ibrahim Awad, in: B. J. J. HARING/A. KLUG (Hgg.), 6. Ägyptologische Tempeltagung. Funktion und Gebrauch altägyptischer Tempelräume. Leiden, 4.-7. September 2002, Wiesbaden 2007, 83-103; W. M. van HaArlem, Temple deposits at Tell Ibrahim Awad, Amsterdam 2009.

12 Kemp, Ancient Egypt, 116-121, fig. 39.

13 R. Bussmann, Der Kult im frühen Satet-Tempel von Elephantine, in J. Mylonopoulos/H. Roeder (Hgg.), Archäologie und Ritual. Auf der Suche nach der rituellen Handlung in den antiken Kulturen Ägyptens und Griechenlands, Wien 2006, 25-36; for a drawing of an updated reconstruction, see R. Bussmann, Scaling the state. Egypt in the Third Millennium, in: Archaeology International 17, 2014, 79-93, fig. 7. DOI 10.5334/ai.1708.

14 EIGNER, Ä\&L 10, fig. 6a and 6 b. 
closures he excavated at Abydos. ${ }^{15}$ A difficulty with this interpretation is the a priori assumption that early shrines were royal building initiatives. It also underestimates the spatial continuity of temple building traditions at many sites, where later royal temples were erected over earlier small mud brick shrines.

Günther Dreyer draws on the Pyramid Texts, among other sources, to explain the meaning of votive figurines found at Elephantine. ${ }^{16}$ These include figurines of human beings, frogs, crocodiles, baboons, and other animals. However, whereas there might have been a shared understanding of certain imagery across society and in different contexts, local interpretation of the image of a baboon, for example, could very well vary.

The use of later and royal texts and architecture for an interpretation of Third millennium community shrines is not wrong per se, but has strong historical ramifications. The more the early shrines are aligned with central, standardised models, the more they comply with the triad of king, gods and temple cult well known from later periods. This core high cultural complex of the New Kingdom and First millennium is extended back to the beginning of Egyptian civilization and almost becomes its essence. However, the dominant framework of royal display in Third millennium Egypt is not the temple cult in the first place, as in later periods, but the funerary context, where the king is the major recipient of offerings. In other words, Egypt's great tradition, which centres on kingship, changes significantly over time and varies in different historical contexts.

\section{Great and little traditions in anthropology}

Kemp's point of departure was the outline of how great central traditions spread in Egypt at the expense of little local traditions. The terms "great" and "little traditions" were coined by the anthropologist Robert Redfield who conducted fieldwork in indigenous society and culture of Yucatan in the 1930s. ${ }^{17}$ In his book "Peasant society and culture" published twenty years later, Redfield argued that central and local traditions constantly interacted. He explicitly avoided reifying a set of ideas, objects or practices that belong to either tradition, but was more interested in exchange relationships of different traditions.

Redfield's student McKim Marriott described the exchange mechanisms in greater detail. ${ }^{18} \mathrm{He}$ calls the penetration of central models into local contexts parochialization and the absorption of local models in the centre universalization. Marriott developed his argument in the context of a discussion of primary and secondary civilizations. According to his definition, the latter are more urban and operate at state level, while local village culture, typical of primary civilizations, become a substratum within secondary civilizations. Marriott observed that the form and contents of great traditions varied from village to village. When asked, individual villagers defined the meaning of divine statues that represent deities of the central tradition in entirely different ways.

It is not too difficult to identify similar phenomena in Egypt. The emergence of a secondary civilization could be defined as the state formation period. Parochialization is the gradual implementation of royal ideology in local cults, beginning in the late Third mil-

15 See footnote 5 .

16 For example Dreyer, Elephantine VIII, 78.

17 R. REDFIELD, Peasant society and culture. An anthropological approach to civilization, Chicago 1956.

18 M. Marriott, Little communities in an indigenous civilization, in: M. Marriott (ed.), Village India. Studies in the little community, Chicago 1955, 171-222. 
lennium, whereas the Pyramid Texts, with various local deities arranged around kingship, can be interpreted as an attempt at universalization. Today, it is impossible to interview the villagers of Third millennium BC Egypt. However, if we assume a scenario similar to that in India, they might have come up with diverse interpretations of the meaning of a specific votive figurine, depending on their social and cultural background or even individual experience.

In the 1970s, Louis Dumont and David Pocock objected to the opposition of great and little traditions. ${ }^{19}$ They argued that this distinction was made by an outside analyser and that local and central culture in Hindu India were underpinned by the same binary concepts, such as pure:impure and male:female. According to Dumont and Pocock, practitioners perceive of religion as an integrated field and do not distinguish between great and little traditions.

This approach echoes the question in Egyptology of whether elite and later models apply for a reconstruction of the early Egyptian community shrines. If it is assumed that local and central belief systems were identical the projection of royal architecture into community shrines would be more easily acceptable.

Stanley Tambiah and Jack Goody took a stronger interest in the framework of traditions. ${ }^{20}$ They said that great traditions usually came in writing, whereas oral culture prevailed in village contexts. Since great traditions accumulate over time, they would absorb contradictory contents, whenever new knowledge is added or existing thought re-interpreted.

This certainly is a field Egyptian philology can contribute greatly to. The analysis of textual traditions through time, for example, is increasingly paired with studies of creative misreading and the adaptation of existing knowledge in local contexts or by individual scribes. ${ }^{21}$

Contra Dumont and Pocock, Goody and Tambiah argued that villagers did perceive differences between local and central traditions. To visit a learned monk, for example, would be a decision to invest into knowledge from a higher level authority. Depending on needs, resources, and access, villagers would strategize their interaction with great and little traditions. These observations demonstrate that people behave towards traditions and do not simply reproduce them.

Charles Steward transferred the discussion to Europe. ${ }^{22} \mathrm{He}$ explored the role of devils and demons among the Christian villagers on the island of Naxos. In the introduction of his book, he rejected the rhetoric of Pagan survivals in favour of understanding syncretism as a constant process of remodelling. He also reported that the villagers initially did not speak openly to him about demons and devils, although these "hidden transcripts", to use a

19 L. Dumont/D. Pocock, For a Sociology of India, in: Contributions to Indian Sociology 1, 1957, 7-22; L. Dumont/D. Pocock, Village studies, in: Contributions to Indian Sociology 2, 1957, 23-41 L. Dumont/D. Pocock, On the different aspects or levels in Hinduism, in: Contributions to Indian Sociology 3, 1959, $40-54$.

20 S. J. Tambiah, Buddhism and the spirit cults in North-East Thailand, Cambridge 1970; J. Goody, The logic of writing and the organization of society, Cambridge 1986, 22-32 with examples from Egypt.

21 B. Backes, Zur Anwendung der Textkritik in der Ägyptologie, in: A. Verbovsek/B. Backes/C. Jones (Hg.), Methodik und Didaktik. Herausforderungen eines kulturwissenschaftlichen Paradigmenwechsels in den Altertumswissenschaften, München 2011, 725-738; A. PRIEs, Die Stundenwachen im Osiriskult. Eine Studie zur Tradition und späten Rezeption von Ritualen im Alten Ägypten, Wiesbaden 2011, $448-463$.

22 C. Stewart, Demons and the devil. Moral imagination in modern Greek culture, Princeton 1991. 
term by James Scott, ${ }^{23}$ dominated much of their daily life. Steward showed that the Greek Orthodox Church, which maintained the great tradition on Naxos, accepted deviant belief, unless core tenets of Christian belief were threatened. He lamented the focus on village contexts in anthropology, whereas the role of great and little traditions among urban elites were underexplored.

Steward's case study suggests that the interaction of great and little traditions varies in different societies. Orthodoxy, for example, is not typical of the great tradition in Egypt, probably even not in the Amarna period. The faint evidence of the hidden transcripts in ancient Egypt and the focus of anthropology on village contexts, almost elusive for Egyptologists, make it plain that the transfer of discussions from within anthropology to Egyptology requires discussion.

\section{Great and little traditions in Egyptology}

Historical circumstances might have facilitated the connection between Egyptology and anthropology, more specifically the life of assyriologist Leo Oppenheim. Oppenheim fled Nazi Austria in the 1930s and settled at the University of Chicago. His department was located next door to the anthropology department, where Redfield was teaching and with which Oppenheim maintained close relationships. In his influential 1964 book "Ancient Mesopotamia", Oppenheim argued that the great stream of written tradition - he refers to the neo-Assyrian court libraries in particular - can be properly understood only when set against oral traditions of their time now largely lost, with the exception of less formal letters perhaps. ${ }^{24}$ Although Oppenheim does not mention Redfield, his argument is informed by an appreciation of the impact great and little traditions have upon each other.

Egyptologists who quote Oppenheim's book include Barry Kemp, Jan Assmann and Bruce Trigger. Kemp is one of the first Egyptologist who has written about great and little traditions and also one of the few who substantiates the discussion of little traditions and "folk culture" with archaeological evidence. He argues that great traditions originate in courts, require labour management and subdue other forms of culture. A great tradition "has to colonize the minds of the nation". ${ }^{25}$ Kemp thus sees great and little traditions as opposing each other and as reflecting power relationships.

Jan Assmann developed a binary model of ancient Egyptian culture inspired by structuralist thought. ${ }^{26}$ For Assmann, "memory" and "use" embody two opposing principles that define culture more generally. In this model, memory is the equivalent of a great tradition controlled by the elite and characterised by monumental stone architecture, the fixed in a culture, explicit messages, the hieroglyphic script, constructed realities, meaningful texts and an interregional scope. Use, in contrast, is the embodiment of little traditions, characterised by brick architecture at a human scale, the fluid in a culture, implicit traces, hieratic handwriting, self-evident realities and the local scale. Memory, Assmann believes, is the business of philology and art history, whereas archaeologists deal with use. Assmann further argues that early civilizations were maintained by power and by power only. His is the most explicit attempt at reifying traditions in the record.

23 J. C. Sсотт, Domination and the arts of resistance. Hidden transcripts, New Haven/London 1990.

24 A. L. Oppenheim, Ancient Mesopotamia. Portrait of a dead civilization, Chicago 1964, 12 and 22.

25 KeMP, Ancient Egypt, 111.

26 J. Assmann, Stein und Zeit. Mensch und Gesellschaft im Alten Ägypten, München 1991, 16-31. 
Bruce Trigger, in his comparative discussion of early civilizations, also models great and little traditions in view of power relationships. ${ }^{27}$ Great traditions, he argues, are the culture of the upper classes, take a distinctive shape in different regions of the globe and aim at consistency, whereas little traditions are the culture of the ruled and passive masses, similar in style world-wide, not harmonized, repeating patterns from old and lacking innovative potential.

Kemp, Assmann and Trigger make power a major framework for the discussion. Redfield's initial idea, i.e. to understand the mutual blending of central and local traditions into each other, tends to be downplayed in favour of a binary opposition of two distinctive cultures, one of the rulers and the other of the ruled.

John Baines and Janet Richards add a geographical dimension to the discussion. Baines argues that the temples are the "guardians" of the great tradition in Egypt. ${ }^{28}$ Since they are spread throughout the country, temples would carry the great tradition into milieus outside the political centre, yet were made for inner-elite communication only. Richards argues that the great tradition, which is the tradition of the state maintained in the temples of urban centres, intersects with little traditions, or domestic religion, at the occasion of festivals and processions, for example in the funerary landscape of Abydos. ${ }^{29}$ In Baines' and Richards' argument, consumption of and access to traditions are less clearly cut as in the binary models reviewed above. Geography and landscape bring back people into the equation and show that great and little traditions do not exist as pure ideas but are tied to specific social, historical and spatial contexts.

Approaches to great and little traditions based on textual data take a stronger interest in the contents of traditions, not surprisingly with a preference for the contents of great traditions. According to Joseph Wegner, the literary discourse of the Middle Kingdom constitutes a high tradition. ${ }^{30}$ Wegner describes the great tradition of Egypt as being centred on Pharaoh and kingship and highlights the resilience of this concept over three millennia, a point made earlier by William Murnane and by John Baines and Norman Yoffee in their comparative discussion of Egyptian and Mesopotamian high culture. ${ }^{31}$

Joachim Quack believes that an Egyptological discussion of great and little traditions would have to acknowledge the greater homogeneity of the language in Egypt compared to the multi-ethnic and multi-lingual situation in India. ${ }^{32} \mathrm{He}$ shows that the cultic manuals of the First millennium blend local landscapes into national myth. This knowledge, he says,

27 B. G. Trigger, Understanding early civilizations. A comparative study, Cambridge 2003, 542-543.

28 J. BAINEs, Temples as symbols, guarantors and participants in Egyptian civilization, in: S. QuirKe (ed.), The temple in Ancient Egypt. New discoveries and recent research, London 1997, 216-241, here pp. 225-226.

29 J. E. Richards, Conceptual landscapes in the Egyptian Nile valley, in: W. Ashmore/B. Knapp (ed.), Archaeologies of landscape. Contemporary perspectives, Oxford 1999, 83-100, here page 90.

30 J. Wegner, Tradition and innovation. The Middle Kingdom, in: W. Wendrich (ed.), Egyptian Archaeology, Chichester 2010, 119-142, here pages 119-120.

31 W. J. Murnane, The kingship of the Nineteenth Dynasty. A study in the resilience of an institution, in: D. O’Connor/D. P. Silverman (ed.), Ancient Egyptian kingship, PÄ 9, Leiden 1995, 185-217; J. Baines/N. Yoffee, Order, legitimacy, and wealth in ancient Egypt and Mesopotamia, in: G. Feinman/J. Marcus (ed.), Archaic States, Santa Fe 1998, 199-260.

32 J. F. QuAck, Lokalressourcen oder Zentraltheologie? Zur Relevanz und Situierung geographisch strukturierter Mythologie im Alten Ägypten, in: Archiv für Religionsgeschichte 10, 2008, 5-29. 
was produced by and for literate priests, but was accessible in temple libraries for consultation and exchange among different priesthoods. Quack stresses that great and little traditions only surface in the record integrated with each other and that local traditions can, but do not have to threaten a great tradition. His argument frees great and little traditions from exclusively mirroring power relationships, but leaves it open what the social context for the production and consumption of great traditions outside the priestly milieu was.

David Frankfurter and Jitse Dijkstra contextualise Egyptian religion in the Roman Empire in the light of a discussion of great and little traditions. Frankfurter arranges religious practice in concentric circles, from domestic contexts to community shrines and from regional to interregional temples and finally pan-Mediterranean cults. ${ }^{33} \mathrm{He}$ shows that individuals, such as new prophets, were able to cross these boundaries and participate in different contexts. Frankfurter argues that the Roman Empire embraced a range of existing national great traditions. This situation would have created a context for the emergence of pan-Mediterranean movements, such as Hellenism, the Roman emperor cult and Christianity, with delocalised urban groups functioning as distributers of knowledge. Frankfurter says that local religion is based on practice in the first place rather than on a specific set of beliefs. Even in the late Roman period, indigenous local practice would have continued and long resisted change towards increasing Christianisation in Egypt. Great and little traditions would provide an analytical framework but should not be misunderstood as categories reified in the evidence.

Dijkstra specifies this argument through an analysis of religious change in the regional context of the first cataract. ${ }^{34}$ Departing from Michel de Certeau's approach to practices of appropriation in everyday life, he argues that Christianity provided a new reference framework that people gradually incorporated in their lives. ${ }^{35} \mathrm{He}$ points out, however, that it is impossible to describe how people "became Christian" at the level of the individual due to the lack of relevant evidence and to the fact that religion has been a community affair in the first instance whereas personal experience was nothing that individuals would have recorded.

Frankfurter and Dijkstra engage with a range of issues discussed in anthropology. Of particular interest is their emphasis on the role of local cults for sustaining cultural patterns and on the gap between individuals and cultural resources that they creatively incorporate, adopt or reject. Dijkstra's comment on the source material shows that the formation of the record itself can shed light on the nature of religion as a communal practice, perhaps a thought that could be developed further for the earlier material.

\section{Conclusion: agency and practice}

Great and little traditions have been subject to much controversy in anthropology and do not provide a ready-made framework for the ancient Egyptian evidence. However, discus-

33 D. Frankfurter, Religion in Roman Egypt. Assimilation and resistance, Princeton 1998, 24 and 87-98 on great and little traditions. A critical review of Frankfurter's approach is offered by R. BAGNALL, Models and evidence in the study of religion in late Roman Egypt, in: H. HAHN/S. EMmeL/U. GotTeR (eds.), From temple to church. Destruction and renewal of local cultic topography in Late Antiquity, Leiden 2008, 23-42.

34 J. H. F. Dijkstra, Philae and the end of ancient Egyptian religion. A regional study of religious transformations (298-642 CE), OLA 173, Leven 2008, 1-42.

35 For a theoretical discussion of appropriation, see W. FrIJHOFF, Foucault reformed by Certeau. Historical strategies of discipline and everyday tactics of appropriation, in: Acordia 33, 1998, 92-108. 
sions in anthropology might help with strengthening arguments made about the Egyptian evidence. In turn, the deep chronological structure of the Egyptian record might contribute to understanding important diachronic mechanics of great and little traditions, such as the ways in which knowledge has been accumulated, re-interpreted and adopted to new contexts.

Egyptologists lack the - predominantly oral - evidence for little traditions that anthropologists have at their disposal. However provincial settlements, letters and simple mud figurines, for example, constitute a rich body of useful archaeological, textual and visual material that bears on the question. Moreover, pyramids and temples, traditionally the context for the display of Egypt's great tradition, are places that people interact with in a variety of ways: the secondary use of the valley temple of Mycerinus is an example of appropriation; ${ }^{36}$ central and local practices intersect in the subsidiary Hathor shrine of Mirgissa; ${ }^{37}$ and Thutmosis III includes a simple "fertility figurine" in a royal foundation deposit of Elkab. ${ }^{38}$ These examples show that the interaction of great and little traditions is at work in these contexts, too.

More data of this kind would certainly be helpful for a discussion of great and little traditions in Egyptology. But it is not simply a question of finding great and little traditions in the evidence. In fact, the review above cautions against this idea. Great and little traditions are not things or words, but describe a mechanism. To draw a simple analogy, the "market" is a mechanism of demand and supply. A single commodity, for example a T-Shirt, does not represent demand or supply, but is the output of the interaction of the two, determined by political and social frameworks, economic strategies, and the role of the market in public discourse. Similarly, a votive figurine in Third millennium Egypt is not the representative of either the great or a little tradition, but raises questions about the framework that produced it.

For future research, a clearer distinction can be drawn between traditions and people. People interact and behave towards their cultural environment and do not simply reproduce it. In essence, this is a plea for a more explicit appreciation of key debates of agency discussed across the social and cultural sciences and increasingly also in Egyptology. ${ }^{39}$ This could include a comparison of the contexts in which traditions and people interact, for example during processions, in community shrines or through healing practices. A stronger emphasis on historical and social context prevents a stereotyped portrayal of what great and little traditions are in ancient Egypt and draws attention to the practices in which they interact.

36 Conveniently summarised in Kemp, Ancient Egypt, 307-309, fig. 74.

37 C. Karlin, Le sanctuaire d'Hathor, in: J. Vercoutter (ed.), Mirgissa I, Paris 1970, 307-62.

38 J. E. Quibell, El Kab, ERA 3, London 1898, pl. 21.29.

39 M.-A. Dobres/J. E. Robb (ed.), Agency in archaeology, London 2000; J. C. Barrett, Agency, the duality of structure, and the problem of the archaeological record, in I. HoDDER (ed.), Archaeological theory and practice, Cambridge 2001, 141-164; A. GARDNER (ed.), Agency uncovered. Archaeological perspectives on social agency, power, and being human. London 2004; R. Osborne/J. TANner (eds.), Art's agency and art history, Malden 2007; D. VischaK, Agency in Old Kingdom elite tomb programs. Traditions, locations, and variable meanings, in: M. Fitzenreiter (Hg.), Dekorierte Grabanlagen im Alten Reich. Methodik und Interpretation, London 2007, 255-276; R. Nyord/A. KıøLBY (ed.) "Being in Ancient Egypt". Thoughts on Agency, Materiality, and Cognition. Proceedings of the Seminar held in Copenhagen, September 29-30, 2006, Oxford 2009; S. R. Steadman, Agency and identity in the ancient Near East. New paths forward, London 2010. 
A perspective developed from debates of agency might also help calibrate the degree to which the intentions of ancient individuals are made an argument. Historical discussions of early community shrines tend to be structured around the role of kingship, partially because the earliest archaeological evidence of community shrines chronologically coincides with the early stages of the ancient Egyptian state. This has led to an opposition of royal patronage versus local freedom in scholarly debates, both making the intention of kings a primary factor in their explanation. However, the rise of local temples in the late Fourth millennium might be neither a royal initiative, as one would infer from New Kingdom evidence, nor the outcome of somehow "pristine" local behaviour, but as the result of settlement nucleation and the formation of new hierarchies in village contexts, requiring novel institutions of display. ${ }^{40}$

To what extent early community shrines were modelled on templates of the emerging court culture, which at this point in history were thinly spread throughout the country, might be a question of royal power as well as of availability and knowledge at a local level. Kingship was not only the core of centralised power, but also a resource for distinction. Votive offerings inscribed with a royal name, for example stone vessels of various dates found at Hierakonpolis or Abydos, do not necessarily show that the kings mentioned in the inscription took over control of the shrine, but that the individuals that offered the objects had better access to royal networks through which they acquired the vessels.

One could define, with Marriott, kingship and the emerging court culture in the early Egyptian state as the great tradition of a secondary civilization. Historically, this great tradition and the social environment in which it was embedded gradually formed over one millennium in North-Eastern Africa during the predynastic period during the Fourth millennium. ${ }^{41}$ Although kingship might have been alien to local communities, it was rooted in a social fabric of which these communities were part. Therefore, Egypt's great tradition might have been perceived as embodying values and ideas that were recognisable, perhaps also appreciated, at a local level, even if they were not identical with the traditions that governed life in local communities outside the court.

It will be difficult ever to know which meaning a local inhabitant of Elephantine, for instance, associated with the faience figurine of a crocodile five thousand years ago: whether this meaning was inspired by ideas expressed in the royal Pyramid Texts or by local concepts, and whether it was the material that mattered to the offering individual or the image depicted. However, to acknowledge that meaning does not reside in objects directs research away from synthesising sources of the great tradition for a reconstruction of meaning towards understanding how different agents ascribed meaning to objects in different contexts. What requires further analysis is practice, materiality and changing visual worlds. One line of inquiry for future research could be how the votive imagery came to be relat-

40 R. Bussmann, Temple religion and urbanism in Egypt. A comment on Hierakonpolis, in: JEA 100, 2014, 311-337, here page 334 .

41 B. Midant-Reynes, Aux origines de l'Égypte. Du néolithique à l'émergence de l'état, Paris 2003; D. Wengrow, The archaeology of early Egypt. Social transformations in North-East Africa, 10,000 to 2650 BC, Cambridge 2006; R. J. Wenke, The ancient Egyptian state. The origins of Egyptian culture (c. 8000-2000 BC), Cambridge 2009; for a critical appraisal of neo-evolutionary models, see A. Stevenson, The Egyptian Predynastic and State Formation, in: Journal of Archaeological Research, 2016. DOI: $10.1007 / \mathrm{s} 10814-016-9094-7$. 
ed to the body, as amulets and beads in the same style of the later Old Kingdom and First Intermediate Period clearly demonstrate. ${ }^{42}$

Another open question concerns the role of written knowledge in early community shrines. From a First millennium perspective, one might hypothesize that some kind of library was attached to local temples. The Pyramid Texts, which suddenly appear fully developed in the late Fifth Dynasty, suggest that local knowledge was recorded in writing before it was collected by central government. Certainly, temple libraries, or at least the copy of a local theological treatise or similar, might have existed in ancient times but are not preserved. Yet, the evidence of written documents outside the residence for much of the Third millennium is weak, even if the recent discovery of a set of papyri at Wadi el-Jarf and the use of document seals found at various sites in Egypt could be quoted to the contrary. ${ }^{43}$ Moreover, as Goody, Tambiah and Stewart have argued, writing in premodern societies is restricted to a range of specific purposes. Perhaps one can describe the contexts of writing in ancient Egypt as socially stretched: either within central institutions or whenever the centre touches base with local communities. But the situation of early community shrines is different. These operate below the radar of central government well until the later Third millennium. There was no need to explain or systemise local belief and, consequently, no need for writing.

I hope to have demonstrated that Redfield's model of great and little traditions can be applied beneficially to the Egyptian evidence when anthropological discussions associated with these terms are built into the argument. Just because the terms do not map easily on the ancient Egyptian context, it does not mean that they are useless altogether. The uncertainties that come up in the course of the discussion need not be seen as an obstacle as such, but as a source of inspiration for interpretation.

42 U. Dubiel, Amulette, Siegel und Perlen. Studien zu Typologie und Tragesitte im Alten und Mittleren Reich, OBO 229, FreiburgSchweiz/Göttingen 2008.

43 P. TAllet, Des papyrus du temps de Chéops au Ouadi el-Jarf (Golfe de Suez), in: BSFE 188, 2014, 25-49; J.-P. Pätznick, Die Siegelabrollungen und Rollsiegel der Stadt im 3. Jahrtausend v. Chr. Spurensicherung eines archäologischen Artefakts, Oxford 2005, 61-62; R. Bussmann, The seals and seal impressions from Hierakonpolis, in: EA 38, 2011, 17-19. 


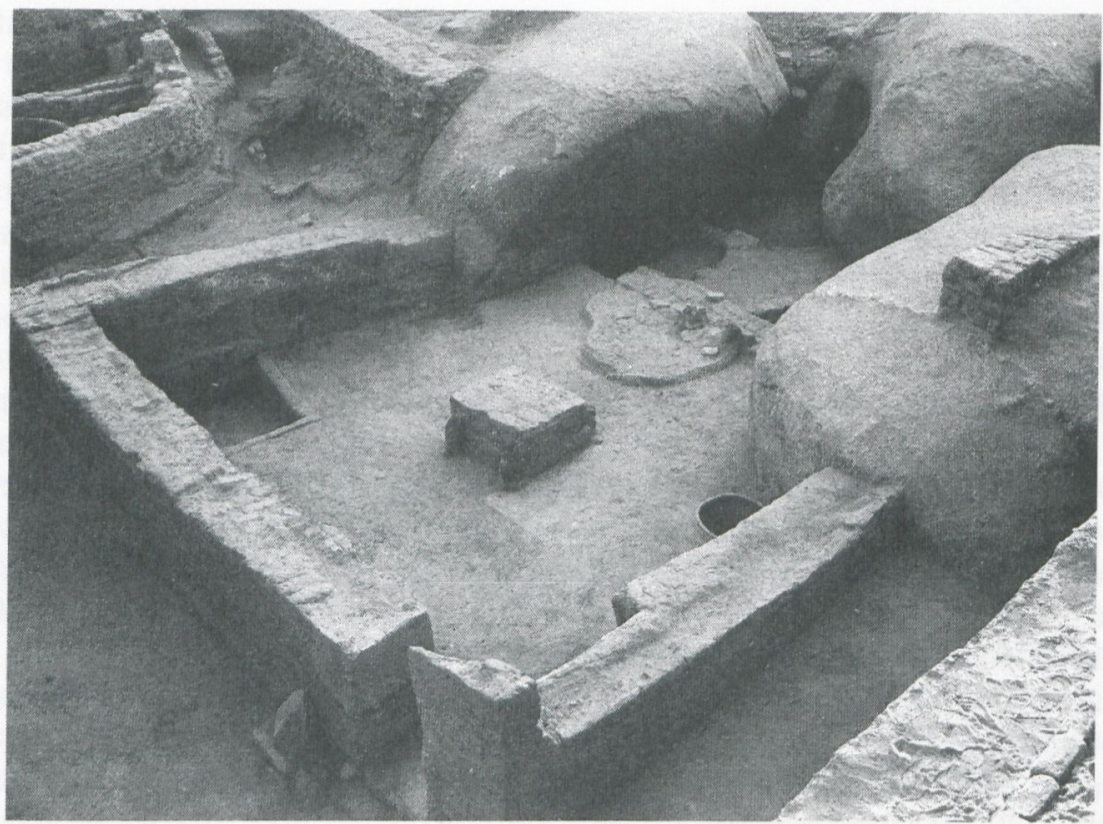

Fig. 1: G. Dreyer, Elephantine VIII. Der Tempel der Satet. Die Funde der Frühzeit und des Alten Reiches, AV 39, Mainz am Rhein 1986, Taf. 2a. Courtesy Deutsches Archäologisches Institut. 